\title{
Adaptive reuse of Sydney offices and sustainability
}

\author{
Sara Jane Wilkinson ${ }^{1, *}$ and Hilde Remoy ${ }^{2}$ \\ ${ }^{1}$ School of Built Environment, University of Technology, Sydney, Australia \\ 2 TU Delft, Netherlands
}

Received: 18 February 2016 / Accepted: 7 February 2017

\begin{abstract}
The built environment contributes $40 \%$ of total global greenhouse gas emissions and $87 \%$ of the buildings we will have in 2050 are already built. If predicted climate changes are correct, we need to adapt existing stock sustainably. Outside Australia there is a history of office to residential conversions. These conversions number few in Sydney although evidence suggests a trend is emerging in conversion adaptations. In 2014, $102000 \mathrm{~m}^{2}$ of office space was earmarked for residential conversion in Sydney as demand for central residential property grows and low interest rates create good conditions. The Central Business District (CBD) population is projected to increase by $4 \%$ to 2031 requiring 45000 new homes and this coincides with a stock of ageing offices. Furthermore, the Sydney office market is set to be flooded with the Barangaroo development supply in 2017; thus conditions for conversion are better than ever. However, what is the level of sustainability in these projects? And, are stakeholders cognisant of sustainability in these projects? Moreover, is a voluntary a mandatory approach going to deliver more sustainability in this market? Through a series of interviews with key stakeholders, this paper investigates the nature and extent of the phenomena in Sydney, as well as the political, economic, social, environmental and technological drivers and barriers to conversion. No major study exists on conversion adaptation in Sydney and the most residential development is new build. There is substantial potential to change the nature of the CBD and enhance sustainability with the residential conversion of office space. The findings show that opportunities are being overlooked to appreciate and acknowledge the sustainability of this type of adaptation and that there is a need for a rating tool to encourage greater levels of sustainability and to acknowledge existing levels of sustainability achieved in these projects.
\end{abstract}

Keywords: residential / conversion adaptation / sustainability / Sydney / mandatory / rating tools / adaptive reuse

\section{Introduction}

According to UNEP [1], the built environment in total adds $40 \%$ to global greenhouse gas (GHG) emissions and to achieve international agreed targets of sustainable development, building related GHG emissions must be cut. The focus is typically placed on the construction of new, sustainable buildings as the best way of delivering reductions; however, adaptation and adaptive reuse is vital as $87 \%$ of the buildings we will need in 2050 are already built [2]. Adaptive reuse is intrinsically sustainable; as it reduces landfill waste, focusing development on the existing built environment, lowering land take for new buildings and infrastructure. Furthermore, with population growth and increasing urbanisation, reuse of existing stock is pragmatic, providing a faster build time compared to demolition and new build [3].

\footnotetext{
* e-mail: sara.wilkinson@uts.edu.au
}

Economic and demographic changes drive transformation in urban settlements, where land uses become obsolete and buildings vacant [4]. Whilst in some regions, demographic and economic decline causes obsolescence and vacancy; in others a spatial shift occurs, with high demands in specific markets and changes of land use resulting. At this point, the potential for existing buildings are demolition or adaptive reuse [5]. Outside Australia, there is a long history adaptive reuse, for example with office to residential conversion in Canada, the US, the UK and the Netherlands [6-10]. In Sydney's central business district (CBD), to date very few residential conversions have occurred, but this may change. Office supply is growing and increasing housing demand in Sydney led to withdrawals of non-CBD office stock for residential conversion [11,12]. $102000 \mathrm{~m}^{2}$ of Sydney office space was earmarked for residential conversion in 2014 as demand for central residential property increases [13] and low interest rates created good conditions. Further, the CBD population is predicted to increase $4 \%$ by 2031 and 45000 new homes are needed to meet demand. The increase 
coincides with a stock of ageing offices [13] and thus conditions look favourable for adaptive reuse. In addition, the office market is set to be flooded with Barangaroo supply in 2016 and 2017. This paper investigates sustainability in the context of conversion adaptation in Sydney, based on literature, interviews with Sydney real estate experts and developers, using case study examples.

Former studies show the potential of delivering sustainability in urban areas by building adaptation, upgrading the environmental performance of existing office buildings [14,15], and the potential to enhance social sustainability in urban areas blighted by vacancy by introducing new functions through adaptive reuse $[16,17]$. This paper explores the potential of adaptive reuse in Sydney, based on the political, economic, social [18], environmental and technological drivers and barriers to adaptive reuse. This research addresses the following:

- What is the level of sustainability in these office conversion adaptation projects?

- Are developers cognisant of the sustainability issues in these projects?

- Is a voluntary or mandatory approach more likely to deliver sustainability?

\section{Sustainability in adaptive reuse}

Economic factors are of the highest importance, where the 'economic lifespan' covers the period in which a property generates more income than cost, or when the present value of all future income is higher than the present value of all future costs. A property has to have economic viability to be considered wholly sustainable. The income a property can generate depends on the price, quality and competition in the market; whilst costs are related to maintenance and operating expenses [19]. In this way, the broader economy has a very profound effect on the economic lifespan of all property, and can shorten or lengthen it considerably. Obsolescence can occur when a building's operational costs, technical or functional characteristics exceed the benefits of occupation; and is termed either economic, technical, or functional obsolescence. At this point, the building will be demolished or adapted [20]. The technical lifespan is the period of time during which the property can meet the technical and physical demands required to use the building and to protect the health and safety of occupants. Whereas the functional lifespan is the period during which a property complies with user's functional demands [21]. Clearly the three types of lifespan are interrelated. For example, if the functional lifespan ends, this usually indicates the economic lifespan also ends. If the functional lifespan ends, it is not possible to find an occupier that means the building can no longer generate income to cover its' costs. Finally, the end of the technical lifespan may cause the end of the functional lifespan; however it is often the case that a building is still in a technically good condition when the end of the functional lifespan is reached [22-24].

Social sustainability characteristics of property can include provision of amenities to enhance the wellbeing and health of occupants. Physical building embodiments of social sustainability could be the provision of a childcare facility in an office building or, a green roof where staff can relax during breaks from work [19]. In commercial organisations social attributes are found in Corporate Social Responsibility (CSR) policies and reports of building tenants and may include charitable donations given, in cash or kind, to less advantaged groups. Furthermore, social aspects may be embodied in an organisations workplace terms and conditions. Social sustainability in housing developments may include social space on rooftops or at ground level or health facilities such as a pool or gym. Though provision of these amenities comes at a cost for residents, in the form of higher rents or purchase price (capital value).

Environmental attributes are considered in respect of eight key categories in the Green Star rating tool, which is the main rating tool in the Australian market. There are many similarities with the attributes adopted in other international rating tools [25]. Building management covers engaging the services of suitably qualified professionals, setting performance targets, having adequate means of metering and measuring consumption of attributes and so on. Within buildings six Indoor Environment Quality (IEQ) sustainability attributes are considered; Indoor Air Quality (IAQ), acoustic, lighting, visual and thermal comfort, and indoor pollutants. Other categories are energy, water, transport, materials, land use and ecology and finally innovation. Innovation includes adoption of an innovative technology or process or improving on Green Star Benchmarks for example. The Green Star Multi Unit Residential v1 tool covered new housing and was withdrawn in December 2015; subsumed into Green Star Designed \& As Built Tool [26]. There are no Australian tools covering adaptive reuse separately. The sustainability attributes that could be embraced by the market in conversion adaptations are illustrated in Table 1. In Europe, BREEAM is the most commonly used tool and BREEAM sustainability attributes are added to Table 1 to shows that although the categories are different, most attributes measured are similar.

Politically Federal, State and Local Governments enact policies and legislation to impact on the level of sustainability. The Building Code of Australia (BCA) mandates minimum standards of energy efficiency and water conservation [27]. The BCA covers all new build and many adaptations; conversions are required to comply with latest minimum standards. However Australian minimum standards embodied in the BCA are low compared to other countries and do not cover the operational phase, thereby buildings may comply with the BCA but still use excessive energy and water resources.

NSW (New South Wales) housing is required to comply with the Building Sustainability Index (BASIX), administered through the National Australian Building Energy Rating Scheme (NABERS). BASIX aims to deliver water and greenhouse gas reductions across NSW, and is one of the strongest sustainable planning measures undertaken in Australia [28]. Integrated into the planning system, BASIX is implemented under the Environmental Planning and Assessment Act 2000 (EP\&A Regulation) and State Environmental Planning Policy (Building Sustainability 
Table 1. Sustainability criteria in adaptive reuse.

\begin{tabular}{|c|c|c|}
\hline & Sustainability criteria Green Star & Sustainability criteria BREEAM \\
\hline Management & $\begin{array}{l}\text { Green Star Accredited } \\
\text { Professional } \\
\text { Commissioning and Tuning } \\
\text { Adaptation and Resilience } \\
\text { Building Information } \\
\text { Commitment to Performance } \\
\text { Metering and Monitoring } \\
\text { Construction Environmental } \\
\text { Management } \\
\text { Operational Waste }\end{array}$ & $\begin{array}{l}\text { Performance assurance } \\
\text { Building site and surroundings } \\
\text { Environmental impact building site } \\
\text { User manual } \\
\text { Consultation } \\
\text { Safety } \\
\text { Knowledge transfer } \\
\text { Maintenance/serviceability } \\
\text { Life cycle costing analysis }\end{array}$ \\
\hline $\begin{array}{l}\text { IEQ in Green Star, } \\
\text { Health and Wellbeing } \\
\text { in BREEAM }\end{array}$ & $\begin{array}{l}\text { Indoor Air Quality } \\
\text { Acoustic Comfort } \\
\text { Lighting Comfort } \\
\text { Visual Comfort } \\
\text { Indoor Pollutants } \\
\text { Thermal Comfort }\end{array}$ & $\begin{array}{l}\text { Daylight admittance } \\
\text { View/vista } \\
\text { Daylight control } \\
\text { High frequency lighting } \\
\text { Indoor and outdoor artificial lighting } \\
\text { Lighting control } \\
\text { Purge ventilation } \\
\text { Internal air quality } \\
\text { Volatile organic compounds } \\
\text { Thermal comfort } \\
\text { Temperature control } \\
\text { Acoustics } \\
\text { Private outdoor space } \\
\text { Accessibility }\end{array}$ \\
\hline Energy & $\begin{array}{l}\text { Greenhouse Gas Emissions } \\
\text { Peak Electricity Demand } \\
\text { Reduction }\end{array}$ & $\begin{array}{l}\text { Energy efficiency } \\
\text { Sub-metering energy use } \\
\text { Energy efficient outdoor lighting } \\
\text { Renewable energy sources } \\
\text { Energy efficient cooling/freezer space } \\
\text { Energy efficient elevators } \\
\text { Energy efficient escalators and ribbons } \\
\text { Guarantee thermal quality facade }\end{array}$ \\
\hline Transport & Sustainable transport & $\begin{array}{l}\text { Availability public transportation } \\
\text { Distance to facilities } \\
\text { Alternative transportation } \\
\text { Pedestrian and bike safety } \\
\text { Traffic plan and parking policy } \\
\text { Traffic information point }\end{array}$ \\
\hline Water & Potable water & $\begin{array}{l}\text { Water usage } \\
\text { Water meter } \\
\text { Leak detection main water supply } \\
\text { Self closing water supply sanitary functions } \\
\text { Water recycling } \\
\text { Irrigation system } \\
\text { Car cleaning service }\end{array}$ \\
\hline
\end{tabular}


Table 1. (continued).

$$
\text { Sustainability criteria Green Star Sustainability criteria BREEAM }
$$

Materials

Land use \& ecology

Ecological value
Sustainable sites
Urban heat island effect
Storm-water
Light pollution
Microbial control
Refrigerant impacts

Pollution

Innovation
Lifecycle impacts

Responsible building materials

Sustainable products

Construction and demolition waste
Building materials
Sustainable products
Robust design
Building flexibility

Waste management building site

Use of recycled material

Storage for reusable material

Compost

Interior

Reuse of land

Polluted land

Plants and animals on building site

Plants and animals as users of the site

Long term sustainable co-use with plants and animals

Efficient land use

GWP (global warming potential) of refrigerants for climate control

Prevent leakage of refrigerants for climate control

GWP of refrigerants for cool and freeze storage

Heating related Nox-emissions

Minimize light pollution

Noise pollution

Innovative technology or process

Market transformation

Improving on Green Star Benchmarks

Innovation challenge

Global sustainability

Source: Authors.

Index: BASIX) 2004 (the BASIX SEPP). BASIX applies to all residential dwelling types and is part of the development application process in NSW. Targets are calculated based on NSW average benchmarks. The targets are; up to a $40 \%$ reduction in potable water consumption and; up to a $40 \%$ reduction in greenhouse gas emissions. BASIX establishes minimum performance levels for thermal comfort in dwellings. The BASIX benchmarks for water are based on average NSW annual potable water consumption from the residential sector, measured on a per capita basis; and for energy: on the average NSW annual GHG emissions from the residential sector on a per capita basis. The benchmarks are determined from NSW average residential water, electricity and gas consumption data collected from state-wide energy utilities by government departments.
The NSW water benchmark is expressed in terms of potable water consumption and is $90340 \mathrm{~L}$ of water per person per annum. Whilst the NSW energy benchmark is $3292 \mathrm{~kg}$ of $\mathrm{CO}_{2}$ per person per year. Australian per capita emissions are amongst the highest in the world [29]. No legislation exists in NSW in respect of landfill waste minimisation or other sustainability attributes for housing. There is little evidence of developers building above these minimum standards. In August 2015 the City of Sydney launched a Residential Apartments Sustainability Plan to encourage the market to reduce environmental impact [30].

Technological aspects considered in sustainable adaptive reuse combine physical building aspects shown in Table 2, and use of less materials and resources, less transport energy and lower pollution during construction. 
Considerations of embodied energy and retention of the structure and fabric is done, where possible, through lifecycle assessment (LCA). Moreover, reductions of operational energy and water consumption belong to technological aspects. Societal aspects include increase of amenities and wellbeing for residents and building users where possible. Rating tools, such as Green Star or BREEAM, could be adopted to evaluate re-use of existing buildings. However, where excessive amounts of deleterious materials, such as asbestos exist, or Sick Building Syndrome is prevalent, adaptive reuse may be neither desirable nor viable.

The potential of offices for residential conversion is well documented [6,19,22,31-34] and described by market, location and building (functional, technical, financial, aesthetic and legal) characteristics.

\section{The office and housing market in Sydney}

Australia's biggest office market is located in Sydney, with the CBD having the biggest share, with $4,961,728 \mathrm{~m}^{2}$ [35]. Office space is categorised using the Property Council of Australia's (PCA) office matrix. Demand for Sydney office space is high, especially in the CBD. Following the Great Financial Crisis (GFC) in 2008, the market grew slightly with vacancy diminishing from $10 \%$ vacancy in 2011 to $9 \%$ by 2015 [11]. Demand for premium sustainable office buildings is high, with this Green Star rated stock commanding higher values and lower vacancy rates [36]. Given the Sydney office market is performing well with decreasing vacancy, good yields, increasing absorption and values, the office market supply is also increasing.

In 2014 , the CBD supply pipeline was $460,000 \mathrm{~m}^{2}$, some $9.3 \%$ of current total stock. Approximately $250,000 \mathrm{~m}^{2}$ of this is Barangaroo, the redevelopment of a container dock area immediately adjoining the CBD. It is highly unusual to get such a large amount of stock coming to market in a relatively short space of time. This stock is due to come onto the CBD office market in 2016 and 2017 and is predicted to cause movement of existing CBD tenants in Premium and A Grade stock into the new Barangaroo stock [11]. In turn, tenants in existing mid-grade CBD office properties are predicted to backfill the vacated premium stock; and a replacement market develops. There will be increased vacancies in mid and lower grade stock as a result [37-39] and a form of relative obsolescence is predicted.

Australia's 2015 housing market is very heated and some banks forecast a slowdown and economic turbulence and uncertainty has been experienced globally at the start of 2016 [40]. Overall prevailing conditions are low interest rates and low unemployment, although this is trending upwards. Melbourne, Sydney and Brisbane have seen high demand from foreign investors for apartments in the CBDs $[11,41]$. Many buyers are Chinese, seeking to invest money in markets, perceived as stable and safe. Many investment apartments purchased by Chinese buyers remain un-let as it is considered unlucky for Chinese people to occupy buildings, which have been already occupied. Having these properties un-let, exacerbates housing affordability prob- lems for many Australians. The superannuation system in Australia encourages citizens to buy investment properties for a retirement income; and this too drives up prices and excludes first time buyers. With turmoil in the Chinese economy and talk of changes to the tax concessions offered to owners of investment property, there is some uncertainty in the Australian housing sector [42].

In recent years residential CBD supply has been very low and stock has been dominated by office use [43]. Over the last decade, urban planners sought to reintroduce mixed use and vitality by allowing more residential land use in CBDs. New units with amenities such as gyms and pools, easy access to work, retail facilities and entertainment, are attractive to some buyers and investors. With office tenants moving to newer stock and increasing vacancy in lower grade stock, combined with low interest rates, demand from foreign investors, wealthy immigrants, and increasing urbanisation; housing prices have escalated and thus creates the economic viability to convert older, vacant or partially vacant office stock to residential land use.

\section{Variables influencing adaptive reuse}

\subsection{Location}

Many variables influence the adaptive reuse potential of buildings $[19,31]$. One is the prevailing property market, described above. Location is significant in terms of accessibility and public transport, and access to amenities such as food and other retailing and entertainment. Access to services including healthcare, childcare and education is important for residential stock [44].

\subsection{Building}

Opportunities and risks of adaptive reuse are related closely to the physical characteristics of the existing buildings [31]. To use information from ex-post cases to scan the possibilities for conversion, Remøy and de Jonge [45] defined the building type characteristics that influence the conversion potential, e.g. structure and floors, facade, floor lay-out and the length and depth of the building, and the number and situation of stairs and lifts. The main load bearing structure in standard office buildings typically has a high conversion potential characterised by a wide span or bay width, few columns, high floors and high load bearing capacity. Low acoustic insulation, high beams and (in older properties) a dense structural grid reduce conversion capacity. Interventions in the facade represent substantial costs and reduce conversion potential. Furthermore cantilevered floors with curtain walling reduce the possibility to add balconies and subdivide the facade to accommodate new interior walls. Overall, well-maintained facades in good technical condition, with a dense grid, increase the conversion potential. Also large floor plates and building depth increase the conversion potential of office buildings. The location of lifts and staircases has a high impact on the lay-out, as relocating stairs and elevators adds significantly to building costs. A high number of lifts in offices increase conversion potential as lift 
Table 2. Physical building characteristics affecting adaptive reuse potential.

\begin{tabular}{|c|c|c|}
\hline & Positive & Negative \\
\hline \multirow[t]{3}{*}{ Structure and floors } & Large floor spans & Dense grids \\
\hline & Columns; free plans & Low ceilings under existing beams \\
\hline & Constructed for heavy carriage & Thin floors: acoustic insulation insufficient \\
\hline \multirow[t]{2}{*}{ Facade } & Small grid & $\begin{array}{l}\text { Inadequate technical state, no attachment-points } \\
\text { for interior walls }\end{array}$ \\
\hline & Good technical state & $\begin{array}{l}\text { Cantilevering floors: complicates adding } \\
\text { balconies }\end{array}$ \\
\hline $\begin{array}{l}\text { Floor lay-out, length and } \\
\text { depth }\end{array}$ & Deep buildings & Location of elevators and staircases \\
\hline Stairs and elevators & Excess number of elevators & $\begin{array}{l}\text { Insufficient number of escape routes } \\
\text { Excessive space occupied by cores }\end{array}$ \\
\hline
\end{tabular}

Source: Remøy and Wilkinson [50].

shafts can house HVAC, water supplies and sewer installations. The characteristics affecting office to residential conversion adaptations are summarised in Table 2.

\section{Research method}

This is qualitative research, which shares the three basic assumptions of being naturalistic, holistic and inductive [46]. Naturalism involves seeing the phenomenon in its naturally occurring state, in this case; by interviewing stakeholders and visiting sites to observe what has taken place. The holistic aspect involves looking at the whole problem to develop a more complete understanding of the influencing factors and variables which determine what the most important drivers and barriers for conversion adaptation in Sydney are; how these impact on sustainability, and the level of cognisance of sustainability by developers. The inductive approach is derived from the desktop study and literature review of secondary sources whereby a picture of the problems and issues emerge as the researchers become more familiar with the topic area. The literature review identified which areas needed to be examined and enabled the researchers to compare whether theory and practice are closely matched.

A literature review ascertained the political, economic, social, technological and environmental aspects of office to residential conversion. An application to the UTS Human Research Ethics Committee was approved for data to be collected in January 2015 via semi-structured interviews. This method was selected as it allowed the researchers to collect identical data from each interviewee, in a reasonably relaxed atmosphere $[47,48]$. The unstructured interview was rejected as they can generate data, which is unrelated to the research and is more difficult to analyse [49]. Formal structured interviews were too restrictive, as they would not allow the interviewers to investigate interesting areas that arose during the interview.

The interviews commenced with factual questions to put interviewees at ease. As the interview progressed questions became increasingly complex and finished with questions, which allowed the interviewee to express personal ideas to generate 'richer' deeper information [47]. Each interview took an hour, the optimum time for useful data collection without tiring interviewees. Following Moser and Kalton's [47] recommendations long multi part confusing questions were avoided and jargon was eliminated. There were no leading or biased questions in the interview and the interviewers expressed no views during the interviews to lead or encourage interviewees in any way. Interviews were conducted in February 2015 with experienced developers, consultants and agents with respect to residential adaptive reuse. A total of six interviews were undertaken and given the sample is small, it is not appropriate to quantify their views and the analysis is purely qualitative. The interviewees had experience of working in Europe and Australia, with each having over 15 years work experience, they were knowledgeable and experienced.

The first part ascertained the participants' background, education and experience in order to assess their degree of direct experience with conversion adaptations. The next part of the interview focussed on reasons why buildings are converted in their experience. The attributes found in the literature regarding the technical, physical, legal, social, economic and environmental attributes of conversion adaptation were confirmed as considerations to greater or lesser extents. The interview progressed to a discussion of their opinions of the reasons why a building might not be converted and the barriers to adaptive reuse. The decision 
whether to adapt or demolish was discussed along with reasons why one course of action was chosen. The next stage of the interview comprised a series of statements which interviewees were asked to 'agree' or 'disagree' with. For example, with economic aspects the following statements were posed:

- the development risks are greater in adaptation projects than in new buildings;

- the risks during the construction phase are larger than in adaptation projects for new buildings;

- the costs of adaptation are as high as the cost of demolition and rebuilding;

- revenues of demolition and new construction are higher than for adaptation.

Topics covered in this part of the interview included functional, legal and policy, technical and location. As a result a comprehensive range of topics were covered and opinions stated.

The third part of the interview focussed more on specific projects and examined, the level of sustainability in these office conversion adaptation project, whether the developers were cognisant of the sustainability issues in the projects and whether the interviewee thought a voluntary or mandatory approach more likely to deliver sustainability. The questions were open to facilitate a wide review of the participants' knowledge and experience. Questions included the following:

- To what extent is there potential for office to residential conversion in the Sydney CBD? Why is this? What factors exist? How much stock is suited to retrofit? What attributes does it have?

- Can 45000 units be delivered through conversion of existing buildings in Sydney?

- What are sustainability issues related to residential conversion? How can these issues be optimised and prioritised?

- What lessons may be learned to improve practice and enhance sustainability in conversion adaptation?

- What is the level of sustainability in existing office to residential conversion? Is it measured in any rating tool? If so, what is the tool?

\section{Data analysis}

With regards to sustainability, from the developers perspective, everything is 'market driven' and potential economic risks or gains influence their decisions most. Developers determine what the market is after and look for suitable sites, which may, or may not, have existing buildings. The developers and the valuer agreed that the level of amenities on or surrounding a site is important, such as retail and transport facilities. These attributes are part of the Green Star environmental rating tool and impact on sustainability by reducing the need for private car use for work, shopping and recreation. When a potentially suitable site is found, developers undertake a physical and economic appraisal regarding the potential gains or costs of retaining some, or all, of the buildings. The primary drivers are physical and economic, with sustainability being a secondary consideration, although this may change with the City of Sydney's Residential Sustainability Action Plan launched in August 2015 after the interviews were conducted [30]. Furthermore the economic cycle is crucial, and can impact greatly on profitability. For example the GFC had a very significant impact on the viability of projects commenced in 2007 , where the values and demand changed greatly during project lifecycles. Recent volatility will be impacting on developers making them cautious and risk averse [42]. In most cases developments are developed and sold rather than held, with existing buildings retained only in high value areas, such as the CBD, 'where you have to'. Financially, development risks are greater in adaptive reuse projects than new build.

The valuer/agents agreed economic variables were most important in Sydney's adaptive reuse market, which is experiencing increasing activity especially with 'secondary commercial buildings in Sydney or, certainly it's proposed'. With many valuations the agent saw, buildings have been bought on a proposed redevelopment basis. Significantly investment flows are coming from Asia with 'drivers outside of the real estate for that'; for example; Sydney is perceived as a safe market to 'park' money. It is encouraged, as Australia offers residential visas to people with $\$ 5 \mathrm{M}$ cash to bring into the country. Looking at people who are looking to invest outside of Asia, they seek security for their cash flow and it 'doesn't really matter to them whether the building yields 5\%,6\%, 7\% plus'. Sydney agents advertise the buildings in China to a very high profile and much investment money comes from China, which is heating the property market here. Furthermore there is an enthusiasm in Asia to convert and take a little more risk than Australians might. The current Greenland development in the CBD is a prime example. The agent noted the imminent supply in Barangaroo may lead to oversupply in lower Grade B and C office stock in 2016 and 2017. He concurred with the developers that Highest and Best Use is what determines the use noting that, currently hotels are popular office conversion projects in the CBD. Sydney has high visitor numbers and the major tourist destinations of the Harbour Bridge and Opera House are within walking distance. The biggest risk perceived by the valuer/agent is timing the market cycle, so that your project is ready at a time when demand is high and gave example of buildings which hit the market during the GFC and had to accept much lower rents and purchase prices than estimated $2-3$ years earlier.

With regulatory issues such as planning and heritage, the developers felt there is considerable variation in approach and context from council to council, which can be hard to account for. Changes to the procedures and more uniformity would help to encourage more adaptive reuse. Shortening planning procedures would help as heritage building projects are very protracted. Overall heritage was perceived as an emotional area to deal with which could be positive or negative for developers with potentially higher exposure to risk. One debate focussed on whether heritage is a societal or an individual responsibility. Developers perceived that businesses want to maximise their returns so if that means demolition then a building will be 
demolished, whereas if society values the building, and there was a fund to offset the lower profit resulting from retention, that might work. Again the sustainability attributes such as retention of known and appreciated buildings and landmarks, retention of embodied energy were not considerations or important. The question of whether a mandatory or voluntary approach to sustainability work best has been raised in the commercial office market and early evidence suggests a mandatory approach creates 'a level playing field' for all parties and that stakeholders comply with minimum standards that may be increased over time [44]. Conversely reliance on voluntary actions leads to variations in take up according to fluctuations in the economy [44]. The developers and the valuer felt that in this market social and environmental variables were not as important as economic and legal ones. The developers noted though people feel good about sustainability, they are not prepared to pay extra for it. As embodied carbon in Sydney is not factored into rating tools such as Green Star, the argument regarding retention of existing buildings is not as strong as it could be. This may change in future given the launch of the Residential Apartment Sustainability Plan in August 2015 and the recognition that high density residential has a higher environmental footprint than low density development [30]. The agent agreed embodied carbon is not discussed. There is a perception that developers 'green wash' their developments, which implies a superficial weak sustainability is achieved at best, and that ironically the argument for retained embodied carbon within the existing structure is being missed in this market. Significantly the developers we spoke to acknowledged that inter-generational equity is important. However the current Australian government does not regard sustainability as important, and the developers felt there has to be a push from the population for sustainability to be valued. The valuer noted sustainability is not high on buyer's agendas in the CBD residential market.

Technically, plan shape and the location and number of columns affects ability to accommodate residential units in office conversion projects. The agent noted high construction costs currently due to under supply and high demand in the market. He also noted that older buildings typically pre 1980 have asbestos in them, which adds further to risk, cost and time delays. The valuer thought the location of the service core was important as it can affect the number and size of apartments in a conversion project which again comes back to economics and profits. Again, all attributes raised by interviewees were not considered in the context of sustainability and are very limited given the potential range of attributes identified in Table 2.

\section{Conclusions}

This paper addressed the following questions: (a) what is the level of sustainability in Sydney office conversion adaptation projects? Secondly (b), are developers cognisant of the sustainability issues in these projects? And thirdly, (c) is a voluntary or mandatory approach more likely to deliver sustainability targets? This paper has investigated the nature and extent of residential conversion in Sydney, as well as sustainability and other attributes considered in adaptive reuse. Through interviews held with developers, a consultant and a valuer in the Sydney market, residential conversion in the Sydney CBD importance and awareness of sustainability was investigated.

Various physical, economic, environmental, legal/ regulatory, social and political factors influence and impact on conversion adaptation. In answer to the question; what is the level of sustainability in Sydney office conversion adaptation projects? The level of sustainability achieved is derived from compliance with planning and building legislation and regulation and not from demand from buyers or investors. The results show that financial considerations and risks are the biggest attribute influencing decision-making. If tenants or buyers demanded and were willing to pay for sustainability, developers would increase the level of sustainability. Where deleterious materials such as asbestos or other contamination exists, remediation is undertaken but in terms of compliance with regulation rather than for sustainability reasons per se. The biggest contribution to sustainability is the embodied energy in the original structure, and this is ignored by stakeholders and the rating tools. The rationale is primarily economic in the Sydney market. The second question asked, are stakeholders cognisant of the sustainability issues in these projects? The findings are that interviewees were knowledgeable and aware of some of the sustainability issues that affected adaptive reuse, given the predominance of economic drivers, sustainability was at best; a secondary or tertiary consideration. The development of an adaptive reuse sustainability rating tool may pave the way for increasing awareness of, and recognition of, sustainability in the office to residential adaptive reuse. The third question asked whether: a voluntary or mandatory approach is more likely to deliver sustainability targets? Evidence to date is that a mandatory approach, although slow is a more consistent approach to delivering targets, however the current neo liberal government is very much in the laissez faire school of political thought and it appears to be in the hands of the market currently. The City of Sydney's Residential Apartment Sustainability Plan is a welcome change in this market and may help to focus attention on the significant impact of the residential market on the environment in the short term and possibly help to deliver the much-needed changes.

\section{References}

1. United Nations Environment Program (UNEP), Buildings and Climate Change. Summary for Decision-Makers (2009), http://www.unep.org/sbci/pdfs/SBCI-BCCSummary.pdf (retrieved on: 2015/01/04)

2. M. Kelly, Britain's building stock - a carbon challenge (Presentation, 2008)

3. P.A. Bullen, Adaptive reuse and sustainability of commercial buildings, Facilities 25, 20 (2007)

4. P.W. Koppels, H. Remøy, S. El Messlaki, The negative externalities of structurally vacant offices: an exploration of externalities in the built environment using hedonic price 
analysis, in Paper presented at the ERES 2011, 18th Annual European Real Estate Society Conference, Eindhoven, June 15-18, 2011 (2011)

5. P.A. Bullen, P.E.D. Love, The rhetoric of adaptive reuse or reality of demolition: views from the field, Cities 27, 215 (2010)

6. J. Barlow, D. Gann, Offices into flats (Joseph Rowntree Foundation, York, 1993)

7. R.A. Beauregard, The textures of property markets: downtown housing and office conversions in New York City, Urban Stud. 42, 2431 (2005)

8. A. Coupland, C. Marsh, in The Cutting Edge 1998: the conversion of redundant office space to residential use, edited by RICS Research (University of Westminster, 1998)

9. C. Langston, F.K.W. Wong, E. Hui, L.Y. Shen, Strategic assessment of building adaptive reuse opportunities in Hong Kong, Build. Environ. 43, 1709 (2008)

10. H. Ogawa, K. Kobayashi, N. Sunaga, T. Mitamura, A. Kinoshita, S. Sawada, S. Matsumoto, A study on the architectural conversion from office to residential facilities through three case studies in Tokyo (Paper presented at the Building Stock Activation 2007, Tokyo, 2007)

11. CBRE (2015)

12. N. Saminather, Sydney Office Turn Into Housing Avoiding Shakeout: Real Estate (2014), www.blomberg.com/news/ articles /2014-03-17/sydney-office-turn-into-housing-avoid ing-shakeout-real-estate (retrieved on: 2015/30/01)

13. City of Sydney, Sydney Growth Centres Strategic Assessment Program Report, 2010, www.environment.gov.au/ ../sydney-growth-centres-program-report.pdf (retrieved on: 2015/19/01)

14. S.J. Wilkinson, Office building adaptations and the growing significance of environmental attributes, J. Corp. Real Estate 16, 252 (2014)

15. S.J. Wilkinson, H. Remøy, Sustainability and within use office building adaptations: a comparison of Dutch and Australian practices, in Pacific Rim Real Estate Conference, January 16-19, 2011, Gold Coast, Australia (2011)

16. T. Heath, Adaptive re-use of offices for residential use: the experiences of London and Toronto, Cities 18, 173 (2001)

17. H. Remøy, P.W. Koppels, H. De Jonge, The legacy of the modern movement: appreciation of office locations in the context of the contemporary city, in Corporations and cities conference proceedings, Brussels, TU Delft (2008)

18. S. Tiesdell, T. Oc, T. Heath, Revitalizing historic urban quarters (Architectural Press, Oxford, 1996)

19. S.J. Wilkinson, H. Remøy, C. Langston, Sustainable building adaptation (Wiley, 2014)

20. S.H. Blakstad, A strategic approach to adaptability in office buildings, Faculty of Architecture, Planning \& Fine Arts, Norwegian University of Science \& Technology, Doktor Inegnior 282 (2001)

21. J. Pinder, I. Price, S. Wilkinson, S. Demack, A method for evaluating workplace utility, Prop. Manage. 21, 218 (2003)

22. H. Remøy, Out of office, a study of the cause of office vacancy and transformation as a means to cope and prevent (IOS, Amsterdam, 2010)

23. H. Remøy, D.J.M. van der Voordt, Conversion of office buildings; a cross-case analysis (Paper presented at the BSA 2007, Tokyo, 2007)

24. H. Remøy, D.J.M. van der Voordt, A new life - conversion of vacant office buildings into housing, Facilities 25, 88 (2007)

25. R. Reed, A. Bilos, S.J. Wilkinson, K.W. Schulte, International comparison of sustainable rating tools, J. Sustain. Real Estate 1 (2009)
26. GBCA, Green Star - Multi Unit Residential v1 (2016), https://www.gbca.org.au/green-star/rating-tools/greenstar-multi-unit-residential-v1/ (retrieved on: 2016/04/14)

27. S.J. Wilkinson, Are sustainable building retrofits delivering sustainable outcomes? Pac. Rim Prop. Res. J. 19 (2013)

28. BASIX, NSW Planning and Environment. Planning Tools BASIX (2015), https://www.planningportal.nsw.gov.au/ planning-tools/basix (retrieved on: 2015/08/24)

29. Climate Council, New report reveals that Australia is one of the worst emitters in the world, 2015, https://www.climatecouncil. org.au/new-report-reveals-that-australia-is-among-theworst-emitters-in-the-world (retrieved on: 2016/14/02)

30. City of Sydney, Sydney Residential Apartments Sustainability Plan. A Plan to achieve environmental sustainability in new and existing apartment buildings, 2015, http://www. cityofsydney.nsw.gov.au/__data/assets/pdf_file/0005/ 241538/FINAL-Residential-Apartments-SustainabilityPlan_2015.pdf (retrieved on: 2016/14/02)

31. H. Remøy, D.J.M. van der Voordt, Adaptive reuse of office buildings: opportunities and risks of conversion into housing, Build. Res. Inform. 42, 381 (2014)

32. J. Barlow, D. Gann, Flexible planning and flexible buildings: reusing redundant office space, J. Urban Aff. 17, 263 (1995)

33. T.V.D. Voordt, R. Geraedts, Transformation of office, themes, actors, instruments and projects (2007)

34. R. Geraedts, D.J.M. Van der Voordt, The New Transformation Meter; A new evaluation instrument for matching the market supply of vacant office buildings and the market demand for new homes, in Building Stock Activation 200\%, Tokyo (2007)

35. M3Property, Sydney CBD Office Market (2015), http:// www.m3property.com.au/wp-content/uploads/2015/03/ Sydney-CBD-Office-market-March-2015.pdf (retrieved on: 2015/11/04)

36. G. Newell, H. Peng, S. Yam, Assessing the linkages between corporate social responsibility and A-REIT performance, Pac. Rim Prop. Res. J. 17, 370 (2011)

37. INVESTA, Inveta Quarterly Office Report, Q1 2014 (2014), retrieved 19th February 2015

38. Savills, Sydney Office Quarter Times (2015), http://pdf. savills.asia/asia-pacific-research/australian-research/ australia-office-/savillsresearch-quarter-times-sydney-officeq1-2015.pdf (retrieved on: 2015/24/05)

39. Savills, Spotlight Sydney Residential January 2015 (2015), http://www.savills.com.au/research/australian-research/ residential-market.aspx (retrieved on: 2015/24/01)

40. Australian Financial Review, House Price Forecasts the good the bad and the hopeless (2015), http://www.afr.com/realestate/2015-house-price-forecasts-the-good-the-bad-andthe-hopeless-20151230-glx5ih (retrieved on: 2015/11/04)

41. E.C. Harris, Office to Residential Convert or Redevelop? (2014), http://www.echarris.com/pdf/8502_Office\%20to\% 20Residential\%20Report Final.pdf (retrieved on: 2015/30/ 01)

42. The Australian, Labor's hit on property investors by limiting negative gearing (2016), http://www.theaustralian.com.au/ national-affairs/treasury/labors-hit-on-property-investorsby-limiting-negative-gearing/news-story/caa497d5326c4184 cab243ab840ba68e (retrieved on: 2016/14/02)

43. JLL, Sydney CBD Office Conversions: Manhattan - a template for Sydney? (2014), http://www.jll.com.au/australia/en-au/ Research/Pulse\%20-\%20Sydney\%20Office\%20Conversions\% 20May\%202014.pdf (retrieved on: 19th February 2015/19/02) 
44. S. Wilkinson, J.J. van der Heijden, S. Sayce, Tackling sustainability in the built environment: mandatory or voluntary approaches. The smoking gun? in RICS COBRA Conference, UTS, Sydney, July 8-10th 2015 (2015), ISBN 978-1-78321-071-8, http://www.rics.org/au/knowledge/re search/conference-papers/hybrid-governance-instrumentsfor-built-environment-sustainability-and-resilience-a-compar ative-perspective/

45. H. Remøy, H. De Jonge, Transformation and typology; Vacancy, characteristics and conversion-capacity, in BSA 2007 conference proceedings (Tokyo Metropolitan University, Tokyo, 2007)
46. M.Q. Patton, Qualitative research and evaluation methods (Sage, Thousand Oaks, 2002), third ed.

47. C. Moser, G. Kalton, Survey methods in social investigation (Gower, 1979)

48. J. Bell, Doing your research project (Open University Press, Buckingham, 1995), second ed.

49. C. Robson, Real world research (John Wiley \& Sons, Chichester, 2011), third ed.

50. S. Wilkinson, H. Remoy, Sustainable conversion adaptation: an international comparison of best practices, in RICS COBRA Conference UTS Sydney, July 8-10th 2015 (2015), ISBN 978-1-78321-071-8 2015

Cite this article as: S.J. Wilkinson and H. Remoy: Adaptive reuse of Sydney offices and sustainability. Sust. Build. 2, 6 (2017). 